\title{
PERANCANGAN APLIKASI CUSTOMER RELATIONSHIP MANAGEMENT UNTUK MENINGKATKAN PELAYANAN PADA RUMAH SAKIT ST CAROLUS
}

\author{
Joni Suhartono; ${ }^{1}$ Ardyan Valentino Cahyadi² ${ }^{2}$ David Yunus ${ }^{3}$ \\ 1,2,3 School of Information Systems, BINUS University \\ Jln. K.H. Syahdan No. 9, Palmerah, Jakarta Barat 11480 \\ ${ }^{1}$ jonis@binus.edu; ${ }^{2}$ ardian.valentino@gmail.com; ${ }^{3}$ dove.fit@gmail.com
}

\begin{abstract}
Research aims to create a draft of application based on customer relationship management (CRM) to improve services on St carolus hospital in terms of criticism-suggestions, to create scheduling events and patient schedule for second time which is still less control. Research used survey, interview the parties concerned, as well as analyzing the systems running on St Carolus hospital. Results of the research are application design that helps to improve the quality of the hospital service to the patient, application design that helps management in holding the event, and managing the input given by the visitor at ease. In conclusion, the application design helps manage criticism and suggestions, make events, and intertwine relations with patients after medication or treatment.
\end{abstract}

Keywords: management, communication, information technology, CRM, application design

\begin{abstract}
ABSTRAK
Penelitian bertujuan untuk membuat sebuah rancangan aplikasi berbasis customer relationship management (CRM) untuk membantu meningkatkan pelayanan rumah sakit St Carolus dalam hal kritik-saran, pembuatan event, dan penjadwalan untuk pasien melakukan kontrol ulang yang selama ini masih kurang. Metode yang digunakan dalam penelitian ini adalah survei dan wawancara terhadap instansi terkait serta menganalisis sistem yang sedang berjalan di rumah sakit St Carolus. Hasil yang dicapai dari penelitian ini adalah sebuah rancangan aplikasi yang dapat membantu rumah sakit dalam meningkatkan kualitas pelayanan kepada pasien, rancangan aplikasi yang membantu pengelolaan dalam mengadakan event, serta kemudahan pengelolaan terhadap masukan yang diberikan oleh pengunjung. Simpulan penelitian ini adalah rancangan aplikasi membantu pengelolaan terhadap kritik dan saran, pengadaan event, serta menjalin relasi dengan pasien pascapengobatan atau perawatan.
\end{abstract}

Kata kunci: pengelolaan, komunikasi, teknologi informasi, CRM, rancangan aplikasi 


\section{PENDAHULUAN}

Pelayanan Kesehatan St Carolus (PKSC) (rscarolus, n.d.) merupakan institusi pelayanan kesehatan yang memberikan pelayanannya melalui Rumah Sakit St Carolus dan Balai Kesehatan Masyarakat (balkesmas) yang berada di Jakarta. Dalam pelayanannya PKSC mengutamakan keselamatan pasien dan selalu berusaha memberikan pelayanan dengan penuh kasih. Pelayanan tersebut antara lain seperti monitoring kesehatan pasien dan menanggapi keluhan pasien yang disampaikan kepada pihak rumah sakit. Dengan demikian, melalui hal tersebut, rumah sakit dapat dapat meningkatkan mutu pelayanannya. (rscarolus, n.d.)

Rumah Sakit St Carolus terletak di Jl. Salemba Raya 41. Rumah sakit swasta nonprofit ini milik Perhimpunan St Carolus, di bawah keuskupan Agung Jakarta. St Carolus termasuk RS tipe B dengan kapasitas 386 TT. Sedangkan balkesmas-yang berada di 5 wilayah DKI (Paseban, Tanjung Priok, Klender, Cijantung, dan Cengkareng) - merupakan pelayanan kesehatan yang melayani langsung semua tingkat sosial masyarakat secara paripurna dan terpadu. (rscarolus, n.d.)

Tingginya kebutuhan masyarakat terhadap pelayanan kesehatan membuat makin banyak perusahaan ingin memasuki industri pelayanan kesehatan. Hal tersebut membuat persaingan antarpelayanan kesehatan menjadi lebih ketat. Relasi dengan pasien merupakan salah satu faktor penting yang dapat menunjang keberhasilan pelayanan rumah sakit kepada pasien. Adanya pengelolaan dan komunikasi yang terjalin dengan pasien merupakan salah satu aspek yang diperhitungkan untuk memenangkan persaingan yang terjadi dalam pelayanan kesehatan. Berdasarkan latar belakang tersebut, penulis tertarik untuk mengkaji studi kasus yang berkaitan dengan manajemen hubungan pelanggan dan perancangan sistem e-Customer Relationship Management yang diperlukan untuk mendukung hubungan pelanggan dengan Rumah Sakit St Carolus.

Rumusan masalah dalam penelitian ini adalah sebagai berikut. Pertama, tidak ada proses komunikasi lebih lanjut baik itu satu arah maupun dua arah kepada para pasien pascapengobatan dilakukan. Kedua, dalam pembuatan suatu acara, informasi jelas dibutuhkan agar acara yang diselenggarakan tepat tepat sasaran. Ketiga, media dibutuhkan sebagai penyaluran kritik dan saran agar kualitas rumah sakit makin meningkat sesuai masukan dari pelanggan/pasien.

Sedangkan tujuan dari penelitian ini adalah pertama untuk menganalisis proses yang berhubungan dengan pelayanan pelanggan seperti kritik dan saran, event, maupun monitoring pasien dan merancang sistem e - CRM untuk mendukung pelayanan kesehatan Rumah Sakit St Carolus. Penelitian ini diharapkan dapat membantu pengelolaan hubungan rumah sakit dengan pasien; meningkatkan kualitas hubungan rumah sakit dengan pasien; memudahkan penyampaian informasi ke pasien; meningkatkan kepuasan dan kesetiaan pasien terhadap rumah sakit; memudahkan pengelolaan terhadap kritik dan saran yang diterima rumah sakit demi kemajuan pelayanan; dan memudahkan pasien untuk mendapatkan informasi dari rumah sakit. 


\section{METODE}

Penelitian ini merupakan penelitian eksploratif karena penulis belum mengetahui permasalahan yang biasa dialami oleh Rumah Sakit. Maka dari itu, penulis mendalami studi kasus masalah pada RS St Carolus yang berkaitan dengan pasien, solusi yang dapat diusulkan untuk RS St Carolus, dan bagaimana bentuk e-CRM yang dapat dikembangkan untuk menyelesaikan permasalahan pada Rumah Sakit St Carolus.

Metode-metode yang digunakan dalam penelitian ini antara lain wawancara, survei lapangan, dan studi pustaka. Wawancara dilakukan untuk memperoleh informasi tentang Rumah Sakit, tugas dan kewajiban karyawan dan tenaga medis, persaingan antara rumah sakit, dan kelebihan serta kekurangan dari RS St Carolus. Kemudian survei lapangan dilakukan untuk memperoleh informasi lebih detail tentang Rumah Sakit St Carolus. Penulis turun ke lapangan melakukan survei langsung ke rumah sakit. Survei tersebut dilakukan untuk menganalisis operasional rumah sakit. Sedangkan studi pustaka dilakukan dengan mencari artikel, membaca buku, jurnal online, serta sumber lainnya. Studi pustaka dilakukan guna memperoleh informasi yang dibutuhkan untuk mendukung studi kasus e-CRM.

\section{HASIL DAN PEMBAHASAN}

Greenberg (2010) menjelaskan bahwa Customer Relationship Management (CRM) adalah sebuah filosofi dan strategi bisnis yang didukung oleh sistem dan teknologi yang didesain untuk meningkatkan interaksi manusia dalam lingkungan bisnis. Sementara itu, menurut Monem, Hussin, dan Behboodian (2011) terdapat 3 karakter yang harus diikuti dalam suatu CRM. Little power of customers; pasien membutuhkan banyak informasi namun dukungan untuk memperoleh informasi tersebut yang terkadang tidak ada dari sebuah perusahaan. Information technology; penggunaan teknologi sangat dibutuhkan untuk penerapan CRM ini untuk sinergi antara strategi, pengguna, dan teknologi. Customer Loyalty and Lifelong value; pada usaha kesehatan, kecenderungan pasien loyal sangat banyak terjadi, maka dengan penerapan CRM, diharapkan tingkat loyalitas makin naik.

Menurut Mishra dan Mishra (2009), collaborative CRM berkonsentrasi pada integrasi pelanggan, menggunakan campuran saluran interaksi terkoordinasi (manajemen multi-channel), misalnya toko online, dan call center. Sekitar $60 \%$ dari perusahaan yang disurvei menggunakan portal Internet dalam komunikasi pelanggan mereka untuk dipilih atau kegiatan yang sesuai. Oleh karena itu, CRM dipahami sebagai pendekatan manajemen yang berorientasi pelanggan. Sistem informasi menyediakan informasi untuk mendukung operasional, analitis, dan proses kolaboratif CRM. Dengan demikian berkontribusi terhadap profitabilitas pelanggan dan retensi. Sementara manfaat potensial yang menarik, implementasi CRM harus dikelola dengan hati-hati untuk memberikan hasil.

Lebih lanjut, Zeithaml, Bitner, dan Gremler (2010) mendefinisikan perilaku pelanggan sebagai pelanggan akan menilai pelayanan berdasarkan pengalaman dari generasi yang berbeda dari konsumen memiliki kepribadian yang dibentuk oleh peristiwa, sejarah, dan orang-orang sampai batas tertentu akan mendorong kebutuhan mereka untuk berbagai jenis layanan serta bagaimana mereka ingin hidup dan diperlakukan di tempat kerja. Sebagai contoh orang Amerika, the tradisionalist (lahir antara tahun 1900 hingga 1945) sangat terpengaruh akibat perang dunia, the Roaring Twenties, the Great Deppresion, dan berkarakteristik setia, suka bekerja keras, dan pariotisme. Perbedaan besar dengan mereka yang lahir antara tahun 1946 hingga 1964 serta lahir antara tahun 1981 hingga 1999.

Kemudian, Biswas (2011) mendefinisikan perbedaan cross selling dan upselling. Cross selling merupakan upaya untuk mendorong komitmen pembeli untuk menambahkan item tambahan untuk 
pembelian, seperti aksesori atau item terkait. Sedangkan upselling hanya meyakinkan pembeli bahwa ia harus membeli kualitas yang lebih mahal dan lebih tinggi atau produk yang lebih fleksibel daripada yang sedang dipertimbangkan.

\section{Klasifikasi Rumah Sakit}

Peraturan Menteri Kesehatan No 340 (2010) mengklasifikasikan rumah sakit menjadi empat kelas berbeda, sebagai berikut.

\section{Rumah Sakit Umum Kelas A}

Rumah Sakit Umum Kelas A harus mempunyai fasilitas dan kemampuan pelayanan medic paling sedikit 4 (empat) Pelayanan medic spesialis Dasar, 5 (lima) Pelayanan Spesialis Penunjang Medik, 12 (dua belas) Pelayanan Medik Spesialis Lain dan 13 (tiga belas) Pelayanan Medik Sub Spesialis serta jumlah tempat tidur minimal 400 (empat ratus) buah. Pelayanan Medik Spesialis Dasar terdiri dari Pelayanan Penyakit Dalam, Kesehatan Anak, Bedah, Obstetri dan Ginekologi.

Pelayanan Spesialis Penunjang Medik terdiri dari Pelayanan Anastesiologi, Radiologi, Rehabilitasi Medik, Patologi Klinik dan Patologi Anatomi. Pelayanan Medik Spesialis Lain sekurang kurangnya terdiri dari Pelayanan Mata, Telinga Hidung Tenggorokan, Syaraf, Jantung dan Pembuluh Darah, Kulit dan Kelamin, Kedokteran Jiwa, Paru, Orthopedi, Urologi, Bedah Syaraf, Bedah Plastik dan Kedokteran Forensik.

\section{Rumah Sakit Umum Kelas B}

Rumah Sakit Umum Kelas B harus mempunyai fasilitas dan kemampuan pelayanan medic paling sedikit 4 (empat) Pelayanan Medik Spesialis Dasar, 4 (empat) Pelayanan Spesialis Penunjang Medik, 8 (delapan) Pelayanan Medik Spesialis Lainnya dan 2 (dua) Pelayanan Medik Subspesialis Dasar serta jumlah tempat tidur minimal 200 (dua ratus) buah.

Pelayanan Medik dasar terdiri dari Pelayanan Penyakit Dalam, Kesehatan Anak, Bedah, Obstetri dan Ginekologi. Pelayanan Spesialis Penunjang Medik terdiri dari Pelayanan Anestesiologi, Radiologi, Rehabilitasi Medik dan Patologi Klinik Pelayanan Medik Spesialis Lain sekurang kurangnya 8 (delapan) dari 13 (tiga belas) Pelayanan meliputi Mata, Telinga Hidung Tenggorokan, Syaraf, Jantung dan Pembuluh Darah, Kulit dan Kelamin, Kedokteran Jiwa, Paru, Ortophedi, Urologi, Bedah Syaraf, Bedah Plastik, dan Kedokteran Forensik.

\section{Rumah Sakit Umum Kelas C}

Rumah Sakit Umum Kelas C harus mempunyai fasilitas dan kemampuan pelayanan medic paling sedikit 4 (empat) Pelayanan medic Spesialis Dasar dan 4 (empat) Pelayanan Spesialis Penunjang Medik serta jumlah tempat tidur minimal 100 (seratus) buah. Pelayanan Medik Spesialis Dasar terdiri dari Pelayanan Penyakit Dalam, Kesehatan Anak, Bedah, Obstetri dan Ginekologi. Pelayanan Spesialis Penunjang Medik terdiri dari Pelayanan Anestesiologi, Radiologi, Rehabilitasi Medik, dan Patologi Klinik.

\section{Rumah Sakit Umum Kelas D}

Rumah Sakit Umum Kelas D harus mempunyai fasilitas dan kemampuan pelayanan medic paling sedikit 2 (dua) Pelayanan medic Spesialis Dasar serta dengan jumlah tempat tidur minimal 50 (lima puluh) buah. Pelayanan Medik Spesialis Dasar sekurang kurangnya 2 (dua) dari 4 (empat) jenis 
pelayanan spesialis dasar meliputi Pelayanan Penyakit Dalam, Kesehatan Anak, Bedah, Obstetri dan Ginekologi.

Rumah Sakit St Carolus adalah salah satu bentuk pelayanan kongregasi biarawati Santo Carolus Borromeus di bidang pelayanan kesehatan. Dalam melakukan pelayanan kesehatan, maka rumah sakit Santo Carolus membutuhkan sebuah sistem yang dapat menunjang pengelolaan komunikasi dengan pasien yang telah terkomputerisasi. Analisis dan perancangan dilakukan dalam membangun aplikasi berbasis Customer Relationship Management untuk meningkatkan pelayanan terhadap pasien rumah sakit St Carolus.

Gambar 1 merupakan sistem use case CRM di RS St Carolus. Beberapa aktivitas sistem adalah proses kritik-saran pasien, pembuatan event (acara), jadwal kontrol ulang pasien, follow up pasien.

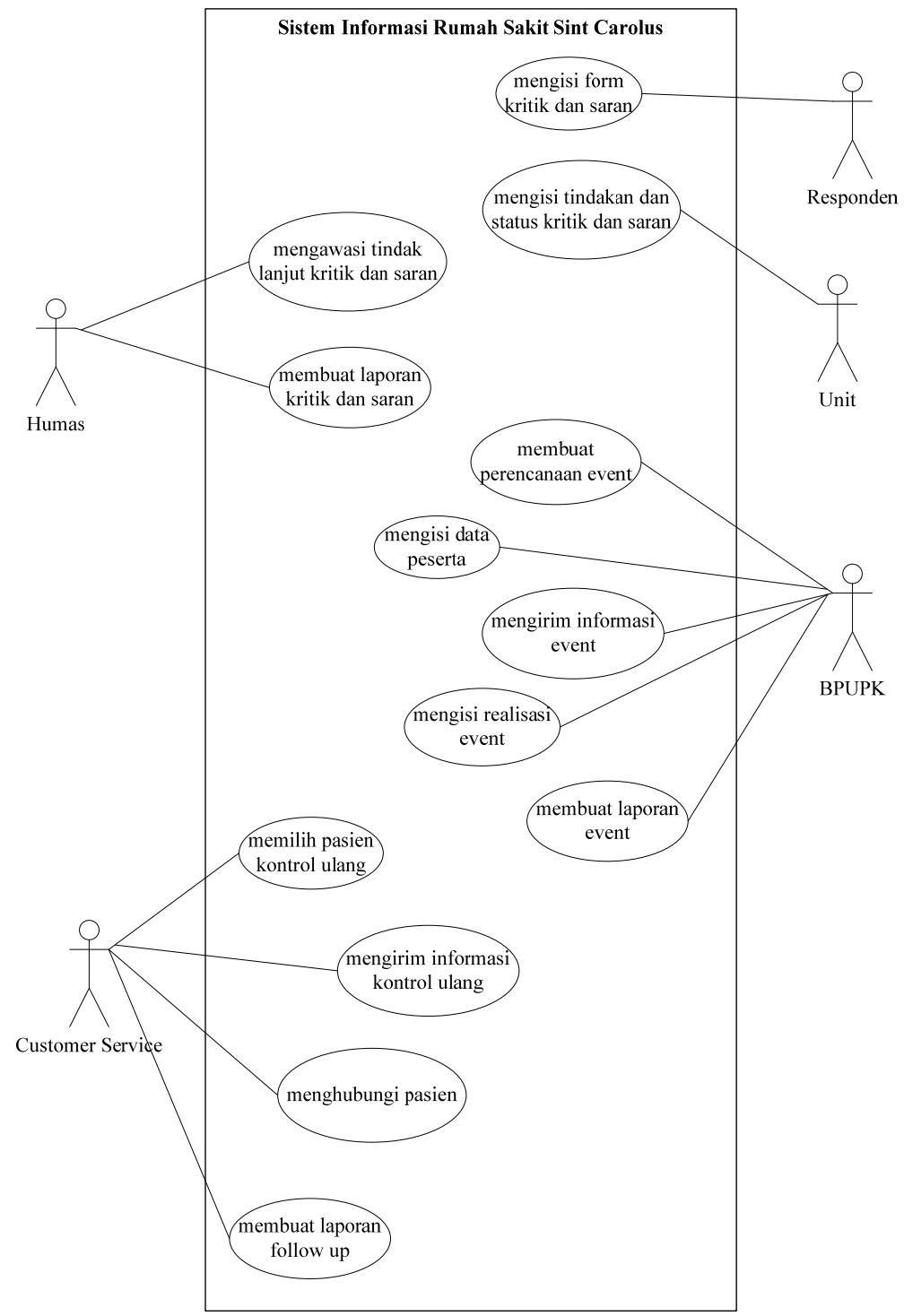

Gambar 1 Use Case System CRM 


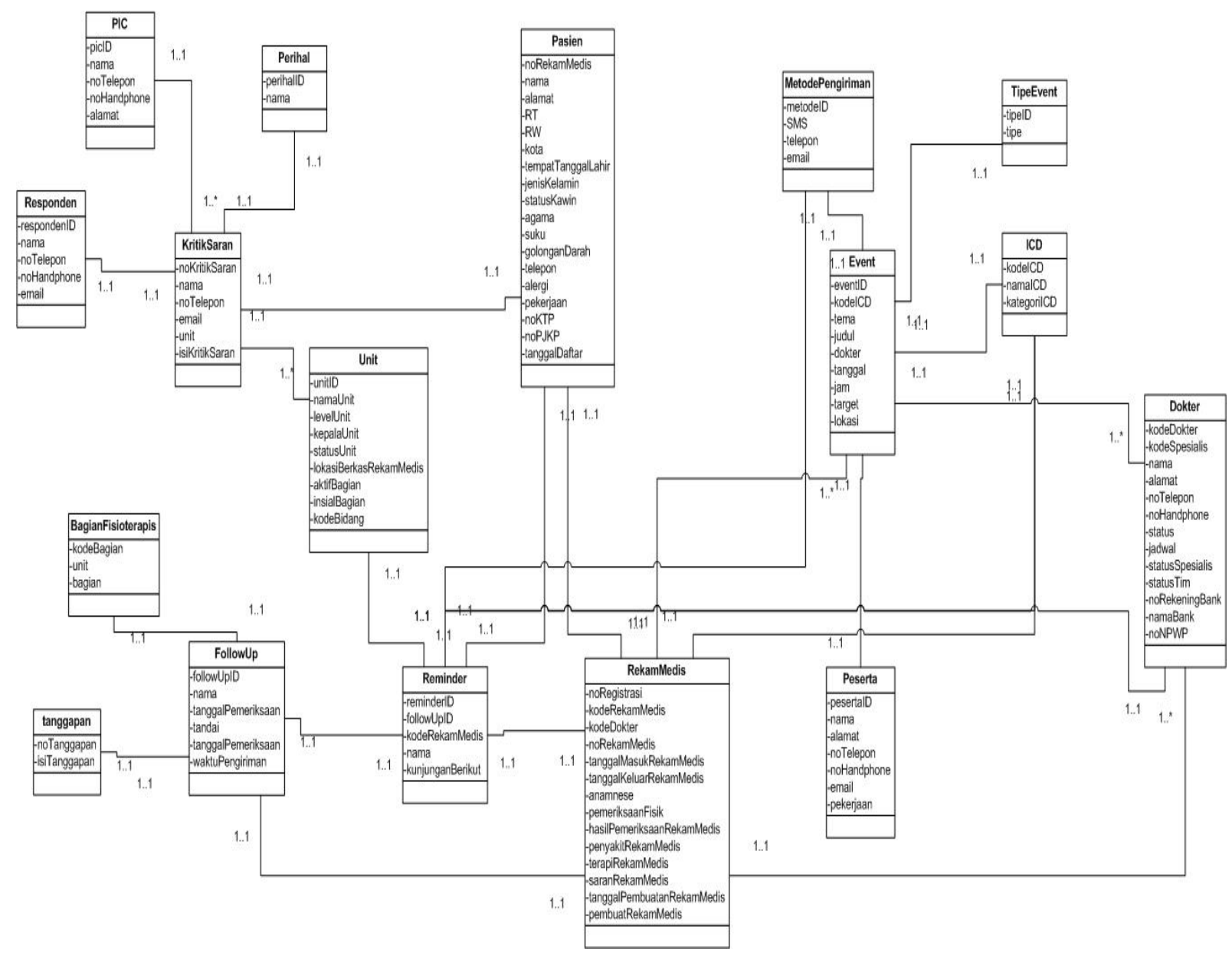

Gambar 2 Class Diagram

\section{Activity Diagram Kritik dan Saran}

Pertama, pengunjung mencatat kritik dan saran. Pengunjung rumah sakit yang memiliki kritik dan saran demi kemajuan pelayanan rumah sakit St Carolus akan mengisi form kritik dan saran. Selanjutnya kritik dan saran yang telah diisi akan terkirim kepada masing masing unit/instansi terkait untuk mendapat tindakan lebih lanjut. Kedua, staf pada unit terkait melakukan update terhadap kritik dan saran. Staf pada unit akan mengisi tindakan yang diambil dalam mengatasi kritik dan saran yang telah diterima serta melakukan update terhadap status kritik dan saran. Ketiga, staff pada Humas melakukan pengawasan terhadap kritik dan saran yang diterima. Staff Humas akan melakukan pengecekan terhadap setiap kritik dan saran yang diterima. Apabila ada kritik dan saran yang tidak mendapat tindakan lebih lanjut, staf Humas akan menanyakan mengenai kritik dan saran tersebut melalui telepon, kepada unit yang bersangkutan. Untuk mengetahui peningkatan terhadap kritik dan saran, maka pihak Humas akan membuat laporan bulanan yang berisi perbandingan dengan bulan sebelumnya serta seluruh kritik dan saran, tindakan dan status terhadap masing masing kritik dan saran. Gambar 3 menunjukkan activity diagram kritik dan saran. 


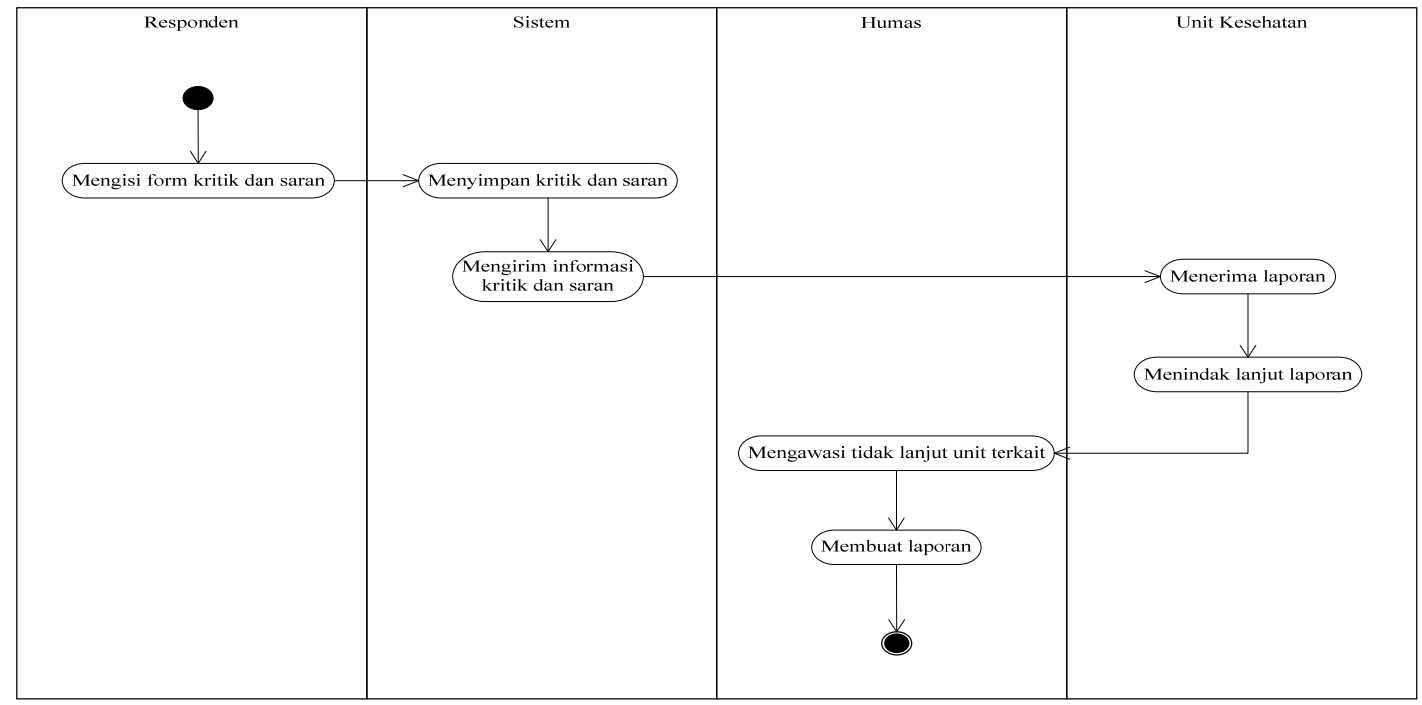

Gambar 3 Activity Diagram Kritik dan Saran

\section{Activity Diagram Perencanaan Event}

Untuk event, pihak BPUPK membuat pengadaan event. Pertama, pihak BPUPK akan mengisi form perencanaan event. Kedua, pihak BPUPK akan mencari target peserta event. Ketiga, pihak BPUPK akan menghubungi calon peserta. Keempat, pihak BPUPK membuat laporan kegiatan tahunan. Gambar 4 menunjukkan activity diagram pengadaan event.

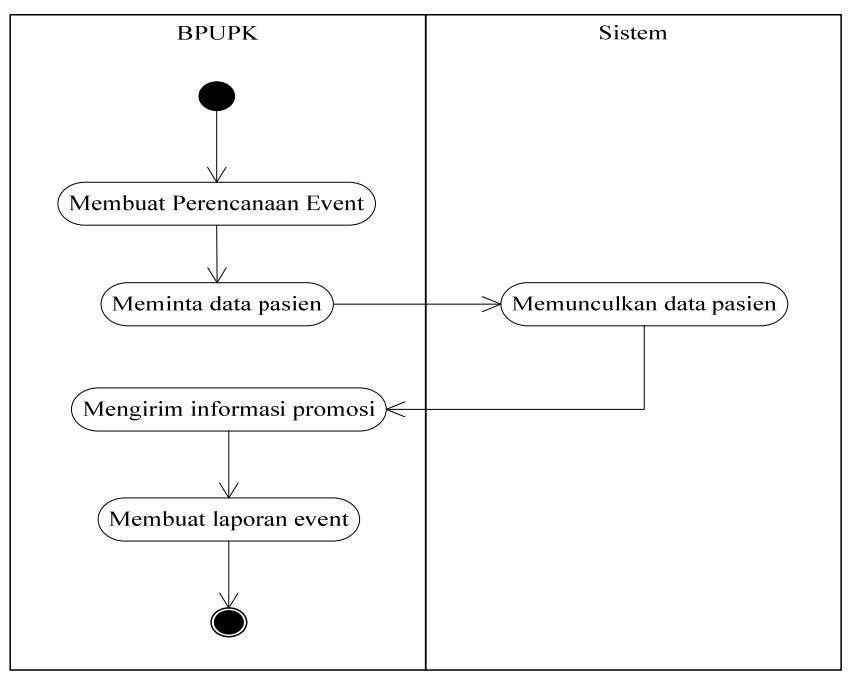

Gambar 4 Activity Diagram Pengadaan Event

\section{Activity Diagram Reminder Pasien}

Pihak customer service, pertama, melakukan pencarian data terhadap pasien yang direkomendasikan untuk melakukan kontrol ulang. Kedua, staf customer service akan mengirimkan informasi atas rekomendasi kontrol ulang. Activity diagram reminder pasien rawat jalan ditunjukkan Gambar 5. 


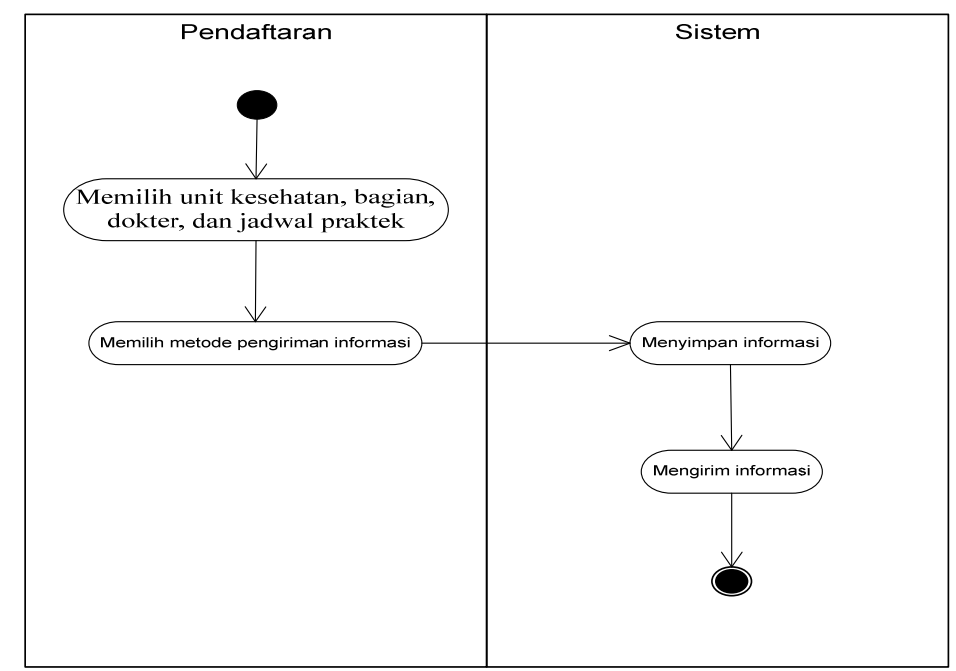

Gambar 5 Activity Diagram Reminder Pasien Rawat Jalan

\section{Activity Diagram Follow up Pasien Fisioterapi}

Pihak customer service, pertama, akan mencari data mengenai pasien yang telah dan akan melakukan fisioterapi lanjutan. Kedua, staf customer service akan menghubungi pasien. Ketiga, staf customer service akan mengisi tanggapan atas hasil fisiotherapi yang telah dilakukan. Keempat, staf customer service membuat laporan terhadap hasil tanggapan dari pasien. Activity diagram follow up pasien fisioterapi ditunjukkan Gambar 6.

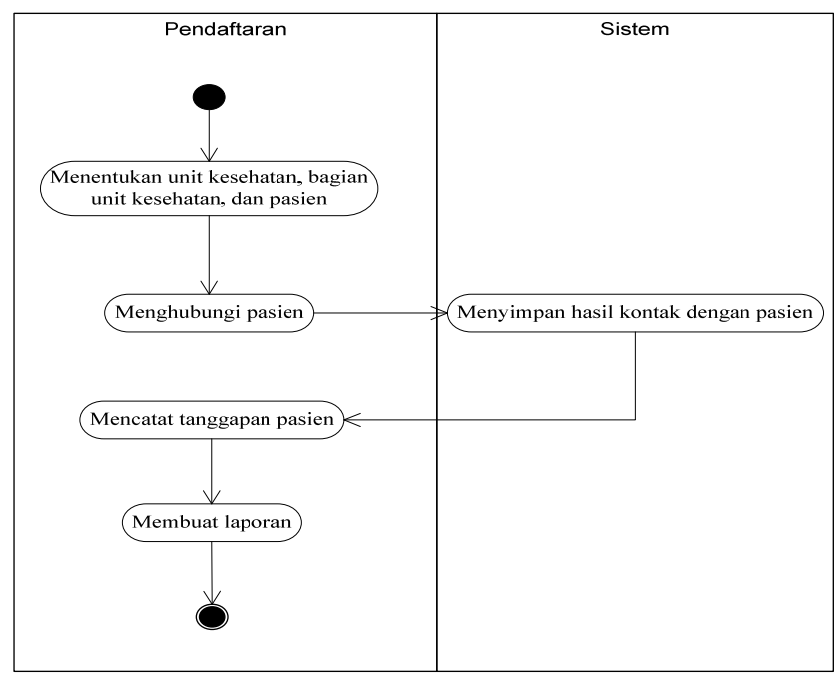

Gambar 6 Activity Diagram Follow up Pasien Fisioterapi

Gambar 7 menunjukkan system sequence diagram three layer membuat perencanaan event. Membuat suatu event harus tepat sasaran baik target peserta, maupun lokasi. Jadi, dengan modul ini staf bisa menentukan topik yang akan dibawakan dan lokasi yang sesuai dengan profil pasien. Proses, sistem membuka class event, selanjutnya user membuat perencanaan dengan menentukan topik, waktu, tempat, lokasi, pembicara, anggaran, dan jumlah peserta. Selanjutnya pada modul yang berbeda, user akan memilih siapa calon peserta yang diharapkan hadir berdasarkan data pasien yang ada. 


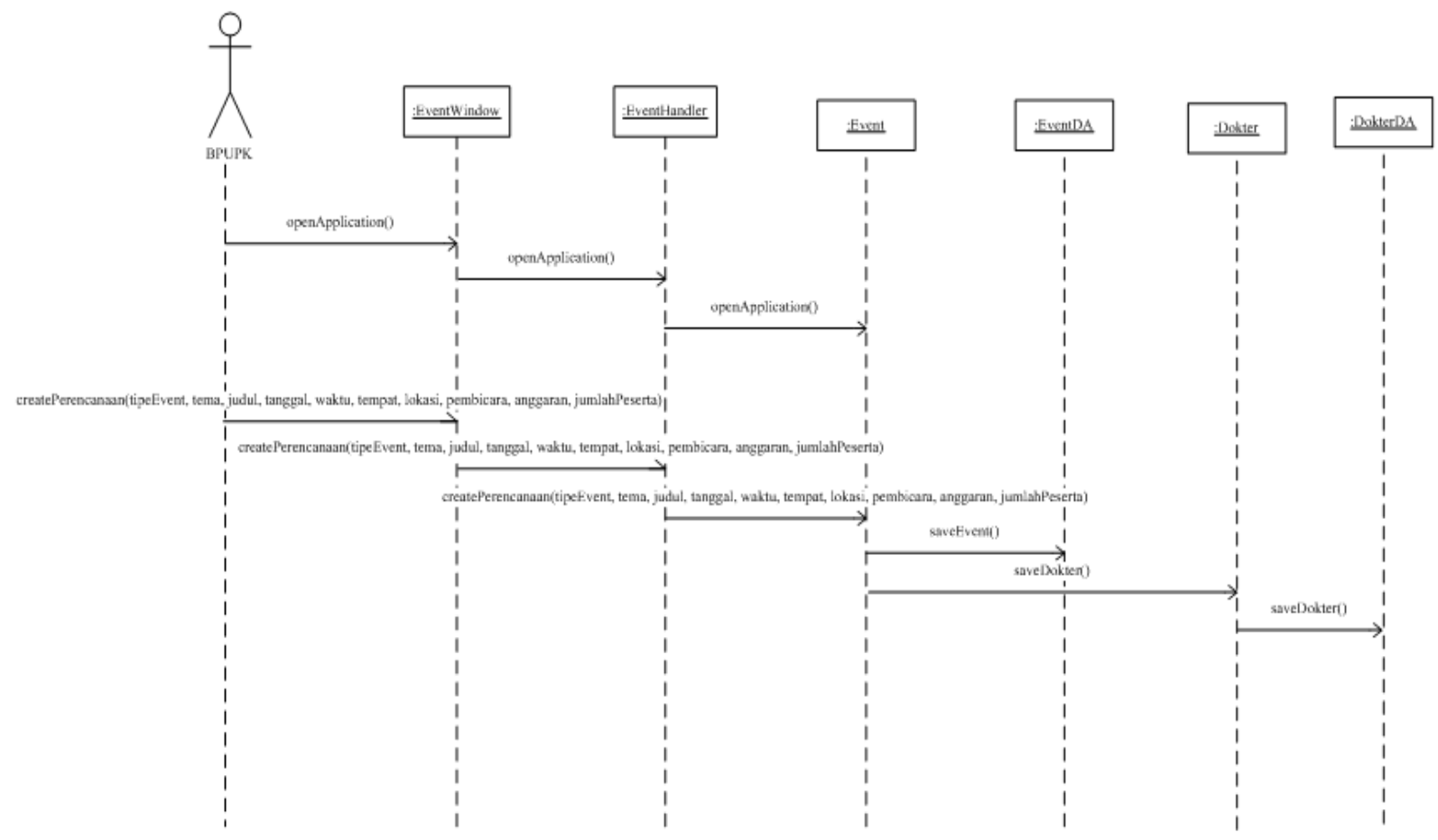

Gambar 7 System Sequence Diagram Three Layer Membuat Perencanaan Event

Pada Gambar 8 ditunjukkan system sequence diagram three layer dalam memilih pasien kontrol ulang. Fungsinya modul ini difungsikan untuk membantu staf mengingatkan pasien untuk kontrol ulang karena banyak sekali pasien yang lupa kapan harus kontrol ke dokter. Jadi, aplikasi ini akan membantu mengingatkan pasien untuk datang kontrol ke dokter. Prosesnya Sistem membuka data rekam medis, tampilkan data pasien sesuai tanggal kunjungan berikutnya; pilih pasien yang akan dikirimkan pesan untuk kontrol ulang; selanjutnya pesan akan terkirim melalui SMS/email. 


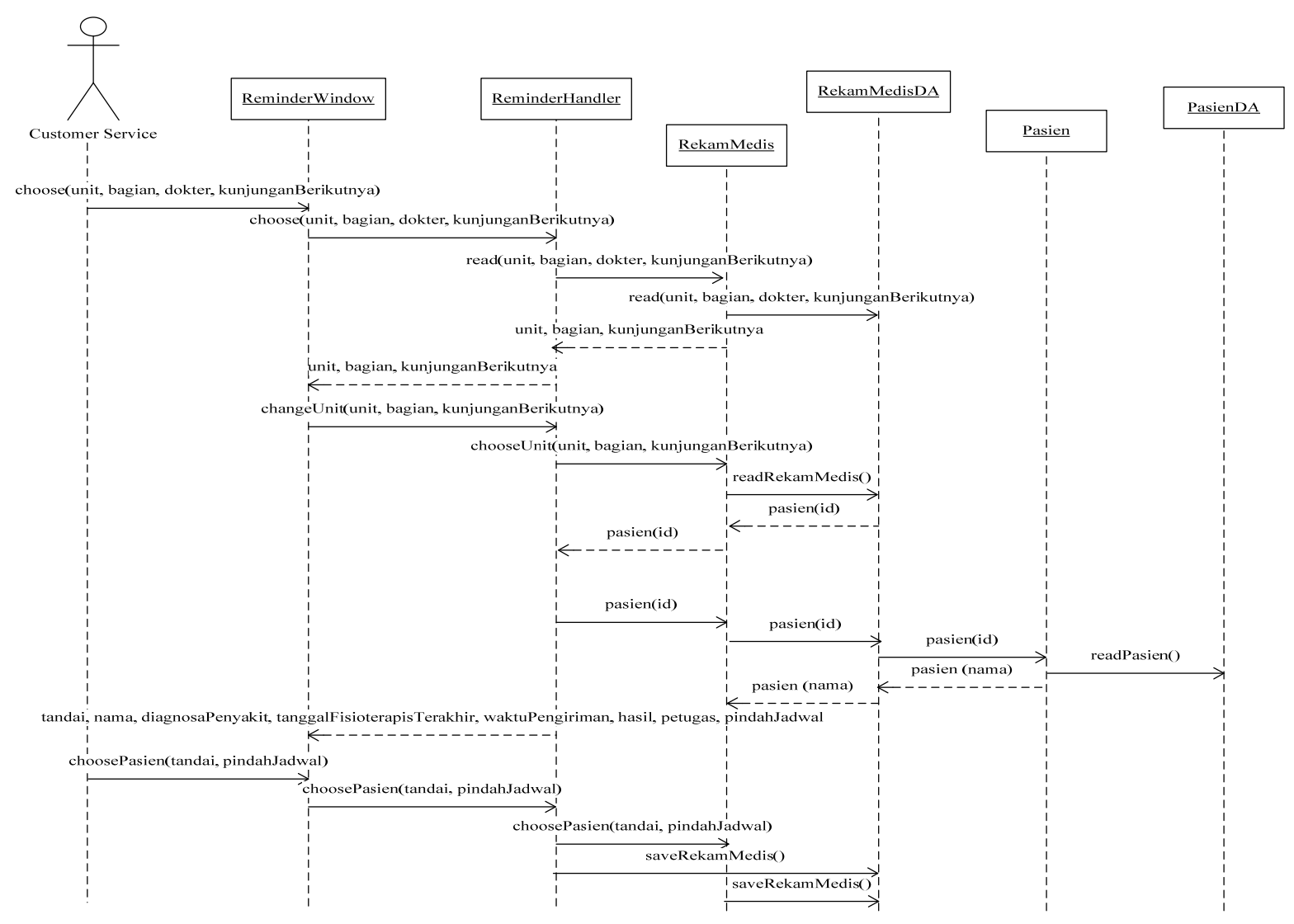

Gambar 8 System Sequence Diagram Three Layer memilih pasien kontrol ulang

Form perencanaan event (Gambar 9) diakses apabila user hendak menambahkan event. Tipe event dibagi menjadi 4 bagian, yaitu: Edukasi, Preventif, Promosi, Kerjasama. Edukasi adalah tipe event yang bertujuan untuk memberikan edukasi kepada peserta. Preventif adalah tipe event yang bertujuan untuk menjaga dan menghindari kejadian tertentu. Promosi adalah tipe event yang betujuan untuk mempromosikan paket paket kesehatan yang ditawarkan oleh rumah sakit St Carolus. Kerja sama adalah tipe event yang diselenggarakan terkait pada pihak lain. Dalam ini, semua field harus terisi. Berikut rinciannya: Chose file (memilih file untuk upload), Create (menambahkan event yang telah diisi ke dalam list tahunan), Reset (mengembalikan semua field kepada nilai awal).

Data peserta event diperoleh dari database pasien yang sesuai dengan event tersebut. Jadi target peserta sudah jelas dan tepat sasaran karena diperoleh dari data pasien sebenarmya. Selanjutnya pasien akan dikirimkan SMS/email sebagai pengingat (reminder) undangan. Pesan ini dikerjakan oleh aplikasi. 


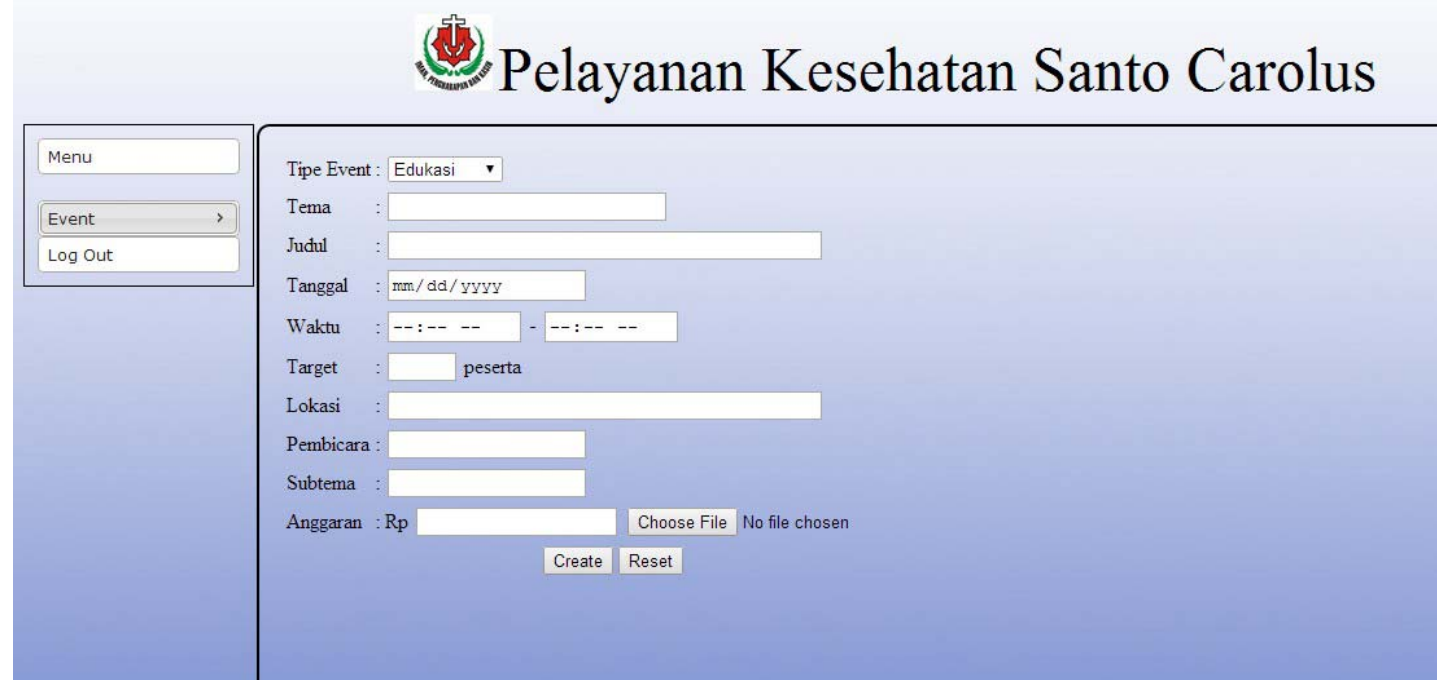

Gambar 9 User Interface Perencanaan event

Pada form reminder pasien (Gambar 10), user dapat memilih pasien yang direkomendasikan oleh dokter untuk melakukan kontrol ulang pada tangal yang telah ditentukan sebelumnya oleh dokter yang bersangkutan. Hal ini dilakukan karena terkadang pasien lupa untuk kontrol ulang. Jadi dengan aplikasi ini, pasien diingatkan untuk datang berobat sesuai jadwal berobatnya. Pesan pengingat ini terkirim bisa melalui SMS maupun melalui email. Berikut rinciannya: Unit pelayanan (pilihan terhadap unit pelayanan yang terdapat pada rumah sakit St Carolus), Bagian (pilihan terdapat bagian yang dimiliki oleh unit pelayanan rumah sakit St Carolus), Dokter (daftar dokter terkait yang menangani bagian bagian tertentu sesuai dengan spesialisasi dokter), Jadwal praktik berikutnya (jadwal praktik berikutnya oleh dokter yang bersangkutan), SMS (pengiriman informasi oleh pihak rumah sakit menggunakan metode Short Message Service), Email (pengiriman informasi kepada pasien menggunakan metode e-Mail), Phone (pengiriman informasi kepada pasien menggunakan telepon).

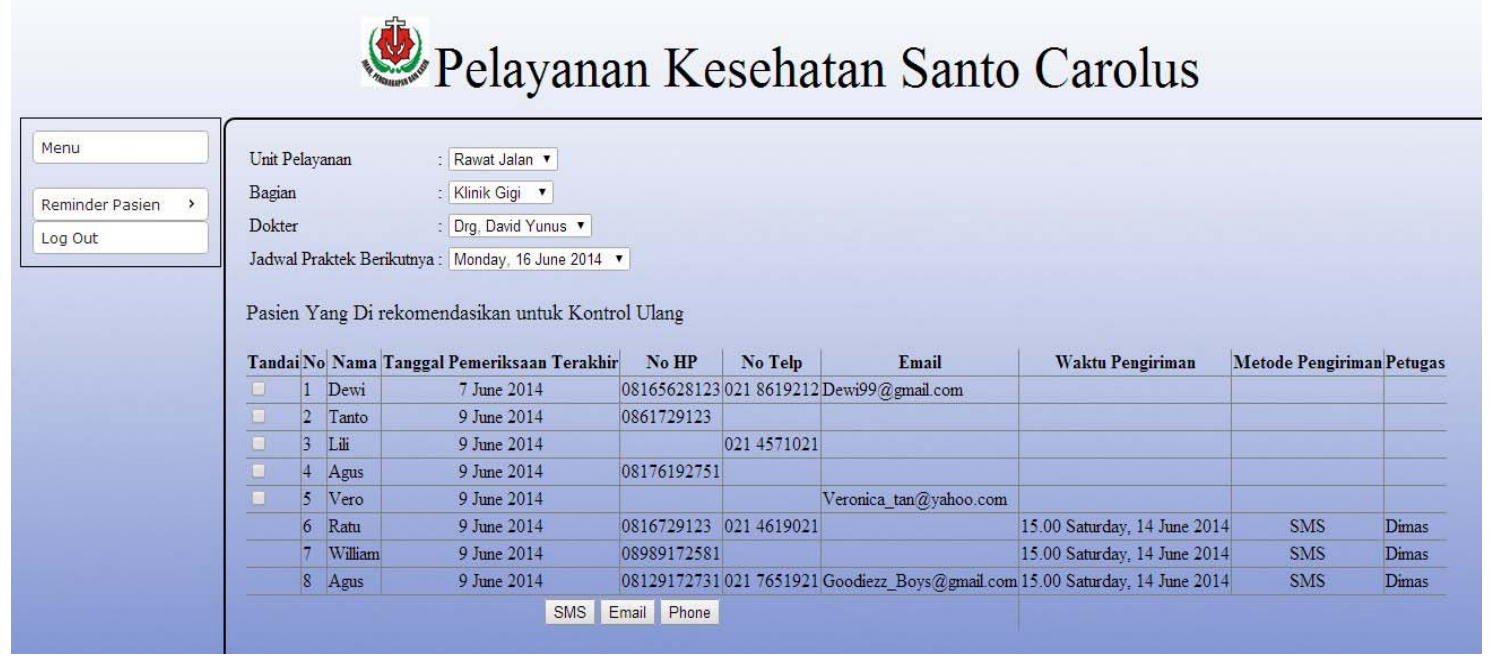

Gambar 10 User Interface Reminder Pasien 


\section{SIMPULAN}

Berdasarkan hasil analisis dan perancangan yang dilakukan dalam penelitian ini, beberapa simpulan dapat diperoleh. Pertama, sistem informasi kritik dan saran memudahkan bagian Humas untuk mengawasi dan menindak lanjuti kritik dan saran yang telah diterima. Kedua, sistem informasi pengadaan event memudahkan bagian BPUPK dalam memilih, menentukan, dan mengirimkan informasi kepada target peserta. Ketiga, sistem informasi reminder kepada pasien memudahkan pengelolaan hubungan antara rumah sakit kepada pasien.

\section{DAFTAR PUSTAKA}

Biswas, S. (2011). Relationship Marketing: Concepts, Theories and Cases. Delhi, India: PHI Learning Private.

Greenberg, P. (2010). CRM at the Speed of Light: Social CRM strategies, Tools, and Techniques for Engaging Your Customer (4 ed.). McGraw Hill.

Mishra, A., \& Mishra, D. (2009). Customer Relationship Management: Implementation process perspective. Acta Polytechnica Hungarica, 6(4), 83-99.

Monem, H., Hussin, A. R. C., Behboodian, N. (2011) Organizational perspective of CRM implementation factors in hospital. International Conference on Research and Innovation in Information Systems, 1-6.

Republik Indonesia. (2010). Peraturan Menteri Kesehatan Republik Indonesia Nomor 340 tentang Klasifikasi Rumah Sakit. Available online http://bppsdmk.depkes.go.id/web/filesa/peraturan/2.pdf

Tentang PKSC. (n.d.). rscarolus.or.id. Diakses dari http://rscarolus.or.id/profil/tentang-pksc/

Zeithaml, V. A., Bitner, M. J., \& Gremler, D. D. (2010). Services Marketing (5 ed.). Wiley. 